field worker in his identification, but the field worker can also help the malacologist. He can send him well-preserved specimens, but above all, he can assist by making notes on the ecology and reproductive condition of the snails, relative to their infection by parasites. It is suspected that there is some direct connexion between the state of the accessory genital glands and susceptibility to infection.

\section{Zoological Nomenclature}

THe International Commission on Zoological Nomenclature gives notice that as from November 6, 1957 , it will start voting on the following cases involving the possible use of its plenary powers for the purposes specified. Full details were published on May 6 in the Bulletin of Zoological Nomenclature (13, Part 5): (1) squilla Linnæus, 1758 (Cancer), suppression; adspersus Rathke, 1837 (Palaemon), designation of, as type species of Palaemon Weber, 1795 (Cl. Crustacea, Order Decapoda); (2) Dracunculus Reichard, 1759, validation of, with Gordius medinensis Linnæus, 1758, as type species (Cl. Nematoda) ; (3) Mansonia Blanchard, 1901 (Cl. Insecta, Order Diptera), validation. Comments should be sent as soon as possible and in duplicate to Francis Hemming, Secretary to the Commission, 28 Park Village East, Regent's Park, London, N.W.1.

\section{Fruit Sap and Seed Germination}

A. Garrard has observed that when the seeds of Fagraea fragrans are removed from their berries, washed, dried and placed on a moist medium, they do not germinate; but germination can be obtained if the whole berry is squashed into the soil, suggesting that the fruit sap contains some substance essential for germination. The relationship of sap to seed germination in a number of succulent fruits was accordingly investigated, with the following results (Gardens' Bull., Singapore, 15, 276; 1956). If a diluted extract of the berry sap of Fagraea fragrans is added to seeds, there is a $90-96$ per cent germination in 12-14 days. The 'active principle' causing germination is filterable and thermostable at $100^{\circ} \mathrm{C}$. Its effect is not due to its hydrogen-ion concentration or to its action as an auxin. Germination can also be effected in washed dried seed by refrigeration at $10^{\circ} \mathrm{C}$. at periods of 1-21 days prior to the germination test. Ten-day-old seed will germinate if supplied with ten-day-old berry sap which has been autoclaved and stored; or if refrigerated prior to testing. The washed dried seeds of Muntingia calabura L. give 61.5 per cent germination on filter paper in distilled water when fully ripe; but this germination is inhibited by sap extracts from its own fruit. The germination of the seed of Melastoma malabathricum L. is unaffected by sap extracts from its own fruit. The germination of the seed of Duranta plumieri Jacq. is inhibited by berry extracts at high concentrations but unaffected at lower concentrations. From the effect of alien sap on seed germination the author considers that it is likely that the active principle affecting the germination of these seeds is the same in all cases.

\section{Sitka Spruce in British Columbia}

Mr. W. R. DAY, of the Imperial Forestry Institute, Oxford, paid a visit to British Columbia to study the Sitka spruce, growing in mixture with associated species in the forests in part of Graham Island and around Terrace in the watershed of the Skeena
River. His report is published in Forestry Com. mission's Bulletin No. 28 (London : H.M. Stationery Office, 1957. 20s. net). Sitka spruce has formed one of the chief components of the new forests of Britain. The work in British Columbia on which the report is based is the result of interest in the development of Sitka spruce in the British plantations stimulated by a variety of problems in which its susceptibility to disease, whether of a non-parasitic or parasitic nature, necessitated attention to the environmental factors which determine the manner of its growth. The problems raised compelled attention to conditions of soil, or of climate, as often basically determining the presence or absence of disease, rate of growth, quality of wood made or length of time on which the rate of growth was likely to be efficient whether from a biological or an economic point of view. One of the difficulties in Britain, where exotic species are chiefly being used in afforestation, is that there is little to indicate the future development of any of the species under conditions differing from those in its native habitat. It was to obtain such information in connexion with the Sitka spruce that Mr. Day undertook the study made of the species in British Columbia. His valuable monograph should prove of use to foresters and botanists alike.

\section{Leverhulme Research Awards, 1957}

The Leverhulme Trustees have approved the following fellowships and research grants, among others, tenable for periods up to two years, the subject of study being indicated in parentheses. Fellowships: Prof. H. 'T. S. Britton, professor of chemistry, University of Exeter (applications of physico-chemical methods to investigations in inorganic chemistry); W. C. Kneale, fellow and lecturer in philosophy, Exeter College, University of Oxford (the development of logic). Research Grants : R. M. Appleby, lecturer in palæontology, University College of Wales, Cardiff (the taxonomy, evolution and affinities of the British ichthyosaurs); Miss B. de Cardi, assistant secretary, Council for British Archæology (archæological excavations in Baluchistan); R. H. Litherland, headmaster, School of Art, Royal Technical College, Salford (methods of teaching engineering design asthetics); Dr. T. Malkin, reader in organic chemistry, University of Bristol (to study facilities for oil and fat research in Europe) ; B. A. O. Randall, lecturer in geology, King's College, University of Durham (geology of the Lyngen Peninsula, Northern Norway); A. W. Reece, senior geologist, Exploration Deportment, Northern Mining Company, Copenhagen (the structure and stratigraphy of N.W. Ankole, Uganda); Dr. J. Smart, lecturer in zoology, University of Cambridge (a study of the black flies of New Guinea and neighbouring lands); J. A. Taylor, lecturer in geography, University College of Wales, Aberystwyth (a systematic analysis of the geography of British farming).

\section{Beit Memorial Fellowships for Medical Research}

The Trustoes of the Beit Memorial Fellowships for Medical Research in their report for 1956-57 announce that Viscount Hailsham has been elected to the Board of Trustees in succession to Lord Simonds. Prof. J. H. Gaddum has been elected to the chairmanship of the Advisory Board in succession to Sir Rudolph Peters, who has resigned after eighteen years membership of the Board. Prof. R. H. S. Thompson has been elected in his place as a member of the Advisory Board. 